medRxiv preprint doi: https://doi.org/10.1101/2021.11.11.21266189; this version posted November 11,2021 . The copyright holder for this preprint (which was not certified by peer review) is the author/funder, who has granted medRxiv a license to display the preprint in

All rights reserved. No reuse allowed without permission.

\title{
Tenofovir Disoproxil Fumarate and severity of COVID-19 in people with HIV infection
}

Del Amo J (1), Polo R (1), Moreno S (2-3), Martínez E (3-4), Cabello A (3,5), Iribarren JA (3,6), Curran A (3,7), Macías J (3,8), Montero M $(3,9)$, Dueñas C $(10)$, Mariño Al $(3,11)$, Pérez de la Cámara S (3,12), Díaz A $(3,13)$, Arribas JR $(3,14)$, Jarrín I $(3,13)$, Hernán MA (15-16) on behalf of the CoVIHd Collaboration in Spain*

1. Division of HIV, STI, Hepatitis and Tuberculosis. Ministry of Health, Madrid, Spain

2. University Hospital Ramón y Cajal Madrid, Spain

3. HIV Network of Excellence, Spain

4. University Hospital Clinic, Barcelona, Spain

5. University Hospital La Concepción, Fundación Jiménez Díaz, Madrid, Spain

6. University Hospital of Donosti, San Sebastian, Spain

7. University Hospital, Vall D'Hebron, Barcelona, Spain

8. University Hospital Virgen de Valme, Seville, Spain

9. University Hospital La Fe, Valencia, Spain

10. University Clinical Hospital of Valladolid, Spain

11. University Hospital El Ferrol, Spain

12. Telemedicine Unit, Institute of Health Carlos III, Madrid, Spain

13. National Center for Epidemiology, Institute of Health Carlos III, Madrid, Spain

14. University Hospital La Paz, IdiPAZ Madrid, Spain

15. CAUSALab, Harvard T.H. Chan School of Public Health, Boston, MA 02115

16. Departments of Epidemiology and Biostatistics, Harvard T.H. Chan School of Public Health, Boston, MA 02115

* Complete list of investigators in Appendix 1

Corresponding author Inma Jarrín (ijarrin@isciii.es)

National Center for Epidemiology, Institute of Health Carlos III Avenida Monforte de Lemos 5, Madrid 28290, Spain

Word count: check: 2,657

Abstract word count: 250 
medRxiv preprint doi: https://doi.org/10.1101/2021.11.11.21266189; this version posted November 11,2021 . The copyright holder for this preprint (which was not certified by peer review) is the author/funder, who has granted medRxiv a license to display the preprint in

All rights reserved. No reuse allowed without permission.

\section{Abstract}

\section{Background}

Effective, safe, and affordable antivirals are needed for COVID-19. Tenofovir has not been studied in randomized trials despite evidence consistent with its effectiveness against COVID19.

\section{Methods}

We studied HIV-positive individuals on antiretroviral therapy (ART) in 2020 at $69 \mathrm{HIV}$ clinics in Spain. We collected data on sociodemographics, ART, CD4-cell count, HIV-RNA viral load, comorbidities and the following outcomes: laboratory-confirmed SARS-CoV-2 infection, COVID19 hospitalization, intensive care unit (ICU) admission and death. We compared the 48-week risks for individuals receiving tenofovir disoproxil fumarate (TDF)/emtricitabine (FTC), tenofovir alafenamide (TAF)/ FTC, abacavir ( $\mathrm{ABC}$ )/lamivudine (3TC), and other regimes. All estimates were adjusted for clinical and sociodemographic characteristics via inverse probability weighting.

\section{Results}

Of 51,558 eligible individuals, $39.6 \%$ were on TAF/FTC, $11.9 \%$ on TDF/FTC, $26.6 \%$ on ABC/3TC, $21.8 \%$ on other regimes. There were 2,402 documented SARS-CoV-2 infections (425 hospitalizations, 45 ICU admissions, 37 deaths). Compared with TAF/FTC, the estimated risk ratios (RR) $(95 \% \mathrm{Cl})$ of hospitalization were $0.66(0.43,0.91)$ for TDF/FTC and $1.29(1.02,1.58)$ for $A B C / 3 T C$, the RRs of ICU admission were $0.28(0.11,0.90)$ for TDF/FTC and $1.39(0.70,2.80)$ for $A B C / 3 T C$, and the RRs of death were $0.37(0.23,1.90)$ for TDF/FTC and $2.02(0.88-6.12)$ for $A B C / 3 T C$. The corresponding RRs of hospitalization for TDF/FTC were $0.49(0.24,0.81)$ in individuals $\geq 50$ years and $1.15(0.59,1.93)$ in younger individuals.

\section{Conclusion}

Our findings suggest that, compared with other antiretrovirals, TDF/FTC lowers COVID-19 severity among HIV-positive individuals with virological control. This protective effect may be restricted to individuals aged 50 years and older. 
medRxiv preprint doi: https://doi.org/10.1101/2021.11.11.21266189; this version posted November 11,2021 . The copyright holder for this preprint (which was not certified by peer review) is the author/funder, who has granted medRxiv a license to display the preprint in

All rights reserved. No reuse allowed without permission.

\section{Introduction}

While vaccine rollout is ongoing, most of the world population remains vulnerable to COVID-19. Therefore, much research has focused on the repurposing of antivirals against SARS-CoV-2. Remdesivir, originally developed against the Ebola virus, was intensively studied from the start of the pandemic ${ }^{1-3}$. More recently molnupiravir, originally developed against the influenza virus, has been reported to reduce the risk of hospitalization and death in high-risk COVID-19 patients ${ }^{4}$.

The repurposing of tenofovir against SARS-CoV-2, however, has not been pursued further despite being a safe and affordable drug that may be effective for the prevention or treatment of COVID-195-9. Three observational studies found lower risks of SARS-CoV-2 antibody prevalence ${ }^{7}$, symptomatic COVID-195, COVID-19 hospitalization, ${ }^{5}$ or COVID-19 mortality ${ }^{5,6}$ among HIV-positive individuals receiving tenofovir disoproxil fumarate/emtricitabine (TDF/FTC) than among those receiving other antiretroviral regimes. Another observational study found a lower risk of severe COVID-19 in patients with chronic hepatitis B virus (HBV) infection treated with TDF/FTC than among those treated with entecavir ${ }^{8}$.

A key unanswered question is whether the association between TDF/FTC and lower risk of serious COVID-19 reflects a causally protective effect of TDF/FTC or simply confounding because TDF/FTC may be used in healthier individuals (e.g., patients with no renal disease) with a lower pre-existing risk of severe COVID-195,10. Distinguishing between a true causal effect and confounding is difficult because no findings from randomized trials of TDF/FTC with clinical COVID-19 outcomes are yet available, and previous observational studies were either not based on a sufficiently large sample of individuals on antiretroviral therapy or did not adjust for a broad range of potentially important confounders.

Here we report the findings from a nationwide cohort study of TDF/FTC and COVID-19 outcomes among HIV-positive individuals on antiretroviral therapy with optimal virological control. We collected data on and adjusted for key potential confounders, including hypertension, diabetes, chronic renal disease, cardiovascular disease, and treatment with immunosuppressants or corticosteroids.

\section{Methods}

\section{Study population}

HIV-positive individuals in Spain receive care at specialized hospital outpatient clinics. The CoVIHd Collaboration (Covid-19 in HIV-positive individuals in Spain) includes HIV-positive individuals who were receiving antiretroviral therapy at the HIV clinics of 87 Spanish hospitals between January 1 and December 31, 2020. All clinics collected information on individuals with 
medRxiv preprint doi: https://doi.org/10.1101/2021.11.11.21266189; this version posted November 11,2021 . The copyright holder for this preprint (which was not certified by peer review) is the author/funder, who has granted medRxiv a license to display the preprint in

All rights reserved. No reuse allowed without permission.

a history of SARS-CoV-2 infection, but this analysis is restricted to the 69 clinics that collected information on HIV-positive individuals with and without a history of SARS-CoV-2 infection. These 69 clinics serve approximately $44 \%$ of all persons on antiretroviral therapy with virological suppression in Spain ${ }^{11}$.

Hospitals transmitted de-identified data to the coordinating center at the Institute of Health Carlos III in Madrid via a secure web-based application specifically designed for this purpose. For each individual, data included sociodemographic characteristics, dates and composition of all antiretroviral therapy regimes received during the study period, latest CD4 cell count and HIV RNA measurements before a COVID-19 diagnosis, comorbidities (from medical records, see Appendix 2), and date of laboratory-confirmed documented diagnosis of SARS-CoV-2 infection defined as positive results from a polymerase chain reaction (PCR) test (or, in a minority of cases, a SARS-CoV-2 antigen test or antibody test), following the Ministry of Health protocols ${ }^{12}$. The ascertainment of hospitalizations due to COVID-19, intensive care unit (ICU) admissions due to COVID-19, and deaths from COVID-19 was complete, but no protocol was in place to systematically screen for asymptomatic infections and mild cases of COVID-19.

\section{Eligibility criteria and follow-up}

We included HIV-positive individuals aged 18 years or older who on February 1, 2020 had not received a diagnosis of SARS-CoV-2 infection and were on antiretroviral therapy, and who had virologically suppression (HIV RNA less than 50 copies/ml) in 2020. Virological suppression is an indicator of adequate adherence to antiretroviral therapy. For each individual, follow-up started on February 1 and ended on December 31, 2020. The goal was to emulate a (hypothetical) target trial in which individuals are randomly assigned to a particular nucleos(t)ide reverse transcriptase inhibitor (NRTI) combination before the start of SARS-CoV-2 transmission in their communities.

\section{Antiretroviral therapy regimes}

We classified antiretroviral therapy regimes according to their NRTI combination into 4 categories: tenofovir disoproxil fumarate (TDF)/emtricitabine (FTC), tenofovir alafenamide (TAF)/ FTC, abacavir (ABC)/lamivudine (3TC), or other drug regimens excluding TDF, TAF and $A B C$. Most of the other drugs category were dual therapies including only one NRTI (3TC) (Appendix Table 1). We also studied regimens with three drugs according to the third drug class used along with the NRTI combination: integrase inhibitor, protease inhibitor, or nonnucleoside reverse transcriptase inhibitor (NNRTI). 
medRxiv preprint doi: https://doi.org/10.1101/2021.11.11.21266189; this version posted November 11,2021 . The copyright holder for this preprint (which was not certified by peer review) is the author/funder, who has granted medRxiv a license to display the preprint in

All rights reserved. No reuse allowed without permission.

Outcomes

The outcomes of interest were any documented laboratory-confirmed diagnosis of SARS-CoV-2 infection and progressively more severe subsets of COVID-19: hospitalization due to COVID-19, ICU admission due to COVID-19, and death due to COVID-19. In supplemental analyses, we also considered documented asymptomatic SARS-CoV-2 infections and mild COVID-19 that did not require hospitalization.

\section{Statistical Analysis}

We calculated the 48-week risk (cumulative incidence) and 95\% confidence interval (Cl) for each outcome by NRTI combination. We estimated the risks using a pooled logistic model with indicators for NRTI combination ( 3 indicators, with TAF/FTC as the reference group), week of follow-up (linear and quadratic terms), and product terms between NRTI combination indicators and week of follow-up. To adjust for baseline prognostic factors, we used inverse probability (IP) weighting. To estimate the denominator of the weights we fit a multinomial logistic model for the four NRTI combinations with covariates: age (in years, linear and quadratic terms), sex (male, female), transmission category (heterosexual, homo/bisexual, injecting drug use, other), country of origin (Spain, other), CD4 (<350, 350-500, $>500$ cells $/ \mathrm{mm}^{3}$ ), and indicators for hypertension, diabetes, chronic renal disease, cardiovascular disease, and treatment with immunosuppressants or corticosteroids. We compared the risks via risk differences and risk ratios and used a nonparametric percentile-based bootstrap with 500 samples to obtain $95 \%$ Cls.

To compare the risks by the non-NRTI drug in the antiretroviral regime, we fit a similar model with indicators for NNRTI, protease inhibitor, and integrase inhibitor. We conducted subgroup analyses by age group ( $<50, \geq 50$ years) and sex for documented SARS-CoV-2 infections, and COVID-19 hospitalization.

We also conducted several sensitivity analyses. To evaluate the potential impact of treatment changes regimes, we conducted an analysis in which individuals were censored if/when they switch from their baseline antiretroviral regime to another regime. To evaluate the potential impact of the choice of inverse probability weighting as the method to adjust for confounding, we repeated the analyses with adjustment via standardization and also estimated adjusted hazard ratios via a Cox regression model. To assess the impact of measured confounding due to comorbidities and other factors, we repeated the analysis with no adjustment at all. All analyses were conducted with Stata, version 15.0 (StataCorp). 
medRxiv preprint doi: https://doi.org/10.1101/2021.11.11.21266189; this version posted November 11,2021 . The copyright holder for this preprint (which was not certified by peer review) is the author/funder, who has granted medRxiv a license to display the preprint in

All rights reserved. No reuse allowed without permission.

This study was approved by the institutional review board at University Hospital Ramón y Cajal, Madrid, Spain.

\section{Results}

Of 51,558 eligible individuals (Figure 1), 39.6\% were receiving TAF/FTC, $11.9 \%$ TDF/FTC, $26.6 \% \mathrm{ABC} / 3 \mathrm{TC}$, and $21.8 \%$ other regimes (see Appendix Table 1 for a description of regimes in each category). The baseline characteristics of individuals in each of the four groups defined by NRTI combination are shown in Table 1. Individuals receiving TDF/FTC and TAF/FTC had similar age, sex, and CD4 cell counts, and were slightly younger than those receiving $A B C / 3 T C$ or other regimes. The proportion of injecting drug users was slightly lower in persons on TAF/FTC than in the other groups. Individuals in the TDF/FTC group had a lower prevalence of hypertension, diabetes, and chronic renal disease than individuals in the other groups.

During the 48-week follow-up, there were 2,402 documented SARS-CoV-2 infections (425 hospitalizations, 45 ICU admissions, and 37 deaths). Of the 1,955 SARS-CoV-2 infections with available information on disease severity, 539 were asymptomatic, 1037 had mild COVID19, 298 moderate COVID-19 and 81 severe COVID-19. Figure 2 shows the estimated cumulative risks of documented SARS-CoV-2 infection, COVID-19 hospitalization, COVID-19 ICU admission, and COVID-19 death by NRTI combination. Appendix Figure 1 shows the risks of asymptomatic COVID-19 and mild COVID-19.

Table 2 shows the estimated 48 -week risks of each outcome by NRTI combination. The estimated risk $(95 \% \mathrm{Cl})$ of documented SARS-CoV-2 infection was $4.3 \%(4.1,4.6)$ for TAF/FTC, 4.5\% $(3.9,5.0)$ for TDF/FTC, and 5.2\% $(4.8,5.6)$ for ABC/3TC. The estimated risks of COVID-19 hospitalization, ICU and death were lowest for TDF/FTC and highest for ABC/3TC (Table 2).

Compared with TAF/FTC, the estimated risk ratio $(95 \% \mathrm{CI})$ of COVID-19 hospitalization was $0.66(0.43,0.91)$ for TDF/FTC, $1.29(1.02,1.58)$ for ABC/3TC, and $0.81(0.62,1.05)$ for others; the estimated risk ratio $(95 \% \mathrm{Cl})$ of COVID-19 ICU admission was $0.28(0.11,0.90)$ for TDF/FTC, $1.39(0.70,2.80)$ for $A B C / 3 T C$, and $0.76(0.23,1.77)$ for others; and the estimated risk ratio $(95 \% \mathrm{Cl})$ of COVID-19 death was $0.37(0.23,1.90)$ for TDF/FTC, $2.02(0.88-6.12)$ for $\mathrm{ABC} / 3 \mathrm{TC}$, and $0.99(0.34,2.61)$ for others (Table 2$)$.

Compared with TAF/FTC, the estimated risk ratios $(95 \% \mathrm{Cl})$ of asymptomatic SARS-CoV2 infection and mild COVID-19 were greater than 1 for TDF/FTC and ABC/3TC. (Appendix Table 2).

Compared with TAF/FTC, the 48-week risk difference of hospitalizations per 1000 persons was $-2.8(95 \% \mathrm{Cl}-5.2$ to -0.8$)$ for TDF/FTC (Table 2$)$. That is, the estimated number 
medRxiv preprint doi: https://doi.org/10.1101/2021.11.11.21266189; this version posted November 11,2021 . The copyright holder for this preprint (which was not certified by peer review) is the author/funder, who has granted medRxiv a license to display the preprint in

All rights reserved. No reuse allowed without permission.

needed to treat with TDF/FTC vs. TAF/FTC during the study period would be 357 (192 to 1250) to prevent one hospitalization.

The estimates were similar in sensitivity analyses that censored at treatment switching (Appendix Table 3), that adjusted for confounding via standardization (Appendix Table 4) or a Cox model (Appendix Table 5), and that did not adjust for any covariates (Appendix Table 6). The risk of COVID-19 hospitalization was similar across the three classes of third drug (Appendix Table 7).

Compared with TAF/FTC, the estimated risk ratio (95\% CI) of COVID-19 hospitalization for TDF/FTC was $0.49(0.24,0.81)$ in individuals aged $\geq 50$ years and $1.15(0.59,1.93)$ in younger individuals (Table 3). The corresponding risk ratio was similar in men and women (Appendix Table 8).

Compared with all NRTI combinations without TDF, the estimated risk ratios $(95 \% \mathrm{Cl})$ of COVID-19 hospitalization, ICU admission and death were 0.64 (0.42-0.89), 0.28 (0.11-0.84) and 0.29 (0.20-1.11), respectively, for TDF/FTC. In individuals aged $\geq 50$ years, these risk ratios were $0.48(0.24-0.76), 0.24(0.18-0.88)$ and $0.22(0.15-0.97)$.

\section{Discussion}

We studied over 50,000 HIV-positive individuals on antiretroviral therapy with adequate virological control in Spain during 2020, before the start of the SARS-CoV-2 vaccination campaign. The estimated risks of COVID-19 hospitalization and ICU admission were lower among individuals treated with TDF/FTC than among those treated with other antiretrovirals. The potential benefit of TDF/FTC appeared to be restricted to individuals over 50 years of age who have a higher risk of developing severe COVID-19. In this age group, the risk of COVID-19 hospitalization was about 50\% lower for TDF/FTC compared with TAF/FTC, the most commonly used NRTI combination. The risk of death from COVID-19 was also lower for antiretroviral regimes based on TDF/FTC, but the estimates were very imprecise. The estimated risks of documented infection and of mild infection are difficult to interpret because of incomplete ascertainment.

Our estimates are consistent with those from observational studies conducted during the first epidemic wave in South Africa ${ }^{6}$ and Spain ${ }^{5}$. These studies, which preferentially included COVID-19 cases that were severe enough to be diagnosed during a period in which only a fraction of cases were confirmed, found a lower risk of severe COVID-19 among HIVpositive individuals on TDF/FTC compared with other NRTI combinations. The latter study did not collect information on comorbidities, used reported population frequencies of antiretroviral use for non-cases (which resulted in a slight overestimation of the proportion of 
medRxiv preprint doi: https://doi.org/10.1101/2021.11.11.21266189; this version posted November 11,2021 . The copyright holder for this preprint (which was not certified by peer review) is the author/funder, who has granted medRxiv a license to display the preprint in

All rights reserved. No reuse allowed without permission.

the population on TDF/FTC and an underestimation of the proportion on TAF/FTC), and did not restrict the analyses to persons with virological suppression ${ }^{5,6}$. Another study in Spain found a lower SARS-CoV-2 prevalence among TDF/FTC users than in TAF/FTC users ${ }^{7}$. The present study improves upon previous ones because it simultaneously includes a large population of HIVpositive individuals with adequate antiretroviral control and adjusts for multiple comorbidities.

Importantly, adjustment for comorbidities and other factors had little impact on our effect estimates, a finding that was not unexpected in our setting ${ }^{13}$ and which we confirm in this study. Because the association between TDF/FTC and a lower risk of severe COVID-19 cannot be fully explained by differences between individuals receiving TDF/FTC and individuals receiving other antiretrovirals, it is likely that the observed association is the result of a causally protective effect of TDF/FTC in HIV-positive individuals. In contrast, individuals on $\mathrm{ABC} / 3 \mathrm{TC}$ had a higher risk of severe COVID-19 than those on other NRTI combinations. While persons on $\mathrm{ABC} / 3 \mathrm{TC}$ (and those on regimes based on dual therapy) are older and have a higher prevalence of comorbidities, the higher relative risk in this group persisted even after adjustment for these factors.

A protective effect of TDF/FTC is biologically plausible. In silico studies suggest that all forms of tenofovir, like other nucleos(t)ide analogues, partly inhibit the SARS-CoV-2 RNAdependent RNA-polymerase (RNAdRNAp) $)^{14-16}$ and some, but not all, in vitro studies also suggest that tenofovir inhibits the RNAdRNAp ${ }^{17,18}$. Because of the possible higher bioavailability of TDF than TAF in respiratory cells, TDF might result in greater inhibition of the SARS-CoV-2 RNApRNAp ${ }^{19-23}$. In addition, tenofovir has been reported to have immunomodulatory effects ${ }^{24-27}$ and animal models suggest that TDF/FTC increases nasopharyngeal SARS-CoV-2 clearance ${ }^{28}$. The possibility of TDF-mediated viral inhibition is further supported by a recent randomized trial that found that TDF/FTC accelerates nasopharyngeal SARS-CoV-2 clearance in HIV-negative individuals within 7 days of COVID-19 symptoms ${ }^{29}$ and another one (not yet peer-reviewed) that reported a lower risk of invasive mechanical ventilation in patients on TDF/FTC + colchicine + rosuvastatin combination ${ }^{30}$. Three ongoing randomized trials are studying the effects of TDF/FTC on clinical outcomes: The EPICOS trial studies TDF/FTC as pre-exposure prophylaxis among healthcare workers in Spain and Latin America ${ }^{31}$, the PANCOVID trial studies TDF/FTC as treatment of COVID-19 in Spain ${ }^{32}$ and the ARTAN-C19 trial in Brazil ${ }^{33}$. The two Spanish trials are led by some of the co-authors of this report.

While the COVID-19 pandemic continues, a protective effect of TDF/FTC has clinical implications for HIV-positive individuals because TDF/FTC is an effective drug to control HIV infection in individuals without impaired renal function ${ }^{34,35}$. Similar considerations apply to 
medRxiv preprint doi: https://doi.org/10.1101/2021.11.11.21266189; this version posted November 11,2021 . The copyright holder for this preprint (which was not certified by peer review) is the author/funder, who has granted medRxiv a license to display the preprint in All rights reserved. No reuse allowed without permission.

individuals with hepatitis B infection. It is possible that a similar protection could extend to HIV-negative individuals, which would be especially important for immunosuppressed patients for whom vaccines have suboptimal effectiveness. Compared with some other drugs repurposed for COVID-19, TDF has several advantages. First, it has a solid safety track record in individuals with normal renal function ${ }^{34}$, including pregnant women ${ }^{35,36}$, and in fact is used routinely as pre-exposure prophylaxis for HIV infection. Second, it is administered orally and thus does not need to be administered in a healthcare facility. Third, it is an inexpensive generic drug that could be massively produced in many countries, including in settings with low COVID-19 vaccine coverage.

Our study has some limitations. First, residual confounding by yet to be identified factors cannot be excluded. However, such residual confounding seems unlikely because we adjusted for known factors that affect both antiretroviral treatment choice and COVID-19 severity. Therefore, the lowest risk of hospitalization in those receiving TDF/FTC cannot be easily explained by residual confounding. Second, we could not collect SARS-CoV-2 testing frequency for all individuals. Testing patterns, however, are expected to affect the detection of mild (and asymptomatic) disease but not that of more severe outcomes like hospitalization, ICU admissions, and death. Third, missing data on comorbidities led to the exclusion of $22 \%$ of otherwise eligible individuals. However, estimates did not materially change in unadjusted analyses that included individuals with missing data on comorbidities. Fourth, even a large cohort like this one cannot provide precise estimates for the risks of infrequent events such as ICU admissions and deaths.

In summary, our findings suggest that treatment with TDF/FTC results in a lower severity of COVID-19 than treatment with other antiretrovirals among HIV-positive individuals with adequate virological control. This protective effect may be largely restricted to individuals aged 50 years and older. Confirmatory randomized trials of TDF/FTC for the prophylaxis and early treatment of COVID-19 are warranted. 
medRxiv preprint doi: https://doi.org/10.1101/2021.11.11.21266189; this version posted November 11, 2021. The copyright holder for this preprint (which was not certified by peer review) is the author/funder, who has granted medRxiv a license to display the preprint in All rights reserved. No reuse allowed without permission.

\section{Funding}

This article is supported by grant R37Al102634 from the U.S. National Institutes of Health, and the Red Temática de Investigación Cooperativa en Sida (RD06/006, RD 12/0017/0018 and RD 16/0002/0006) and grant COV20/01112. PROYECTOS DE INVESTIGACIÓN SOBRE EL SARSCOV-2 Y LA ENFERMEDAD COVID19 (Institute of Health Carlos III, Spain). 
medRxiv preprint doi: https://doi.org/10.1101/2021.11.11.21266189; this version posted November 11,2021 . The copyright holder for this preprint (which was not certified by peer review) is the author/funder, who has granted medRxiv a license to display the preprint in

All rights reserved. No reuse allowed without permission.

\section{References}

1. Mulangu S, Dodd LE, Davey RT, et al. A Randomized, Controlled Trial of Ebola Virus Disease Therapeutics. N Engl J Med 2019;381(24):2293-303.

2. Siegel D, Hui HC, Doerffler E, et al. Discovery and Synthesis of a Phosphoramidate Prodrug of a Pyrrolo[2,1-f] [triazin-4-amino] Adenine C-Nucleoside (GS-5734) for the Treatment of Ebola and Emerging Viruses. J Med Chem 2017;60(5):1648-61.

3. Ansems K, Grundeis F, Dahms K, et al. Remdesivir for the treatment of COVID-19. Cochrane Database Syst Rev [Internet] 2021;(8). Available from: https://doi.org//10.1002/14651858.CD014962

4. Merck. Merck and Ridgeback's Investigational Oral Antiviral Molnupiravir Reduced the Risk of Hospitalization or Death by Approximately 50 Percent Compared to Placebo for Patients with Mild or Moderate COVID-19 in Positive Interim Analysis of Phase 3 Study. [Internet]. Available from: https://www.merck.com/news/merck-and-ridgebacksinvestigational-oral-antiviral-molnupiravir-reduced-the-risk-of-hospitalization-or-death-byapproximately-50-percent-compared-to-placebo-for-patients-with-mild-or-moderat/

5. Del Amo J, Polo R, Moreno S, et al. Incidence and Severity of COVID-19 in HIV-Positive Persons Receiving Antiretroviral Therapy: A Cohort Study. Ann Intern Med 2020;173(7):53641.

6. Boulle A, Davies M-A, Hussey H, et al. Risk factors for COVID-19 death in a population cohort study from the Western Cape Province, South Africa. Clin Infect Dis Off Publ Infect Dis Soc Am 2020;

7. Berenguer J, Díez C, Martín-Vicente $M$, et al. Prevalence and factors associated with SARS-CoV-2 seropositivity in the Spanish HIV Research Network Cohort. Clin Microbiol Infect Off Publ Eur Soc Clin Microbiol Infect Dis 2021;S1198-743X(21)00343-8.

8. Muñoz-Mateos B, Buti M, Fernandez I, et al. Tenofovir reduces the severity of COVID19 infection in chronic hepatitis B patients. J Hepatol 75(2):S746-7.

9. DeJong C, Spinelli MA, Okochi H, Gandhi M. Tenofovir-based PrEP for COVID-19: an untapped opportunity? AIDS Lond Engl 2021;35(9):1509-11.

10. Del Amo J, Polo R, Moreno S, et al. Antiretrovirals and Risk of COVID-19 Diagnosis and Hospitalization in HIV-Positive Persons. Epidemiol Camb Mass 2020;31(6):e49-51.

11. Centro Nacional de Epidemiología, Instituto de Salud Carlos III, Plan Nacional sobre el Sida, Dirección General de Salud Pública. Unidad de vigilancia del VIH, ITS y hepatitis. Actualización del Continuo de Atención del VIH en España, 2017-2019 [Internet]. 2020;Available from: https://www.mscbs.gob.es/ciudadanos/enfLesiones/enfTransmisibles/sida/vigilancia/home.ht $\mathrm{m}$

12. Ministerio de Sanidad. Interpretación de las pruebas diagnósticas frente a la SARSCoV-2 [Internet]. 2020;Available from:

https://www.mscbs.gob.es/profesionales/saludPublica/ccayes/alertasActual/nCov/documento S/INTERPRETACION_DE_LAS_PRUEBAS.pdf

13. Alejos B, Suárez-García I, Bisbal O, et al. Choice of the initial antiretroviral treatment 
medRxiv preprint doi: https://doi.org/10.1101/2021.11.11.21266189; this version posted November 11,2021 . The copyright holder for this preprint (which was not certified by peer review) is the author/funder, who has granted medRxiv a license to display the preprint in

All rights reserved. No reuse allowed without permission.

for HIV-positive individuals in the era of integrase inhibitors. PloS One 2019;14(8):e0221598e0221598.

14. Elfiky AA. Ribavirin, Remdesivir, Sofosbuvir, Galidesivir, and Tenofovir against SARSCoV-2 RNA dependent RNA polymerase (RdRp): A molecular docking study. Life Sci 2020;253:117592.

15. Zanella I, Zizioli D, Castelli F, Quiros-Roldan E. Tenofovir, Another Inexpensive, WellKnown and Widely Available Old Drug Repurposed for SARS-COV-2 Infection. Pharmaceuticals 2021;14(5):454.

16. Copertino DCJ, Casado Lima BC, Duarte RRR, et al. Antiretroviral drug activity and potential for pre-exposure prophylaxis against COVID-19 and HIV infection. J Biomol Struct Dyn 2021;1-14.

17. Clososki GC, Soldi RA, Silva RM da, et al. Tenofovir Disoproxil Fumarate: New Chemical Developments and Encouraging in vitro Biological Results for SARS-CoV-2. J Braz Chem Soc 2020;31(8):1552-6.

18. Chien M, Anderson TK, Jockusch S, et al. Nucleotide Analogues as Inhibitors of SARSCoV-2 Polymerase, a Key Drug Target for COVID-19. J Proteome Res 2020;19(11):4690-7.

19. Seifert SM, Chen X, Meditz AL, et al. Intracellular Tenofovir and Emtricitabine Anabolites in Genital, Rectal, and Blood Compartments from First Dose to Steady State. AIDS Res Hum Retroviruses 2016;32(10-11):981-91.

20. Patterson KB, Prince HA, Kraft E, et al. Penetration of tenofovir and emtricitabine in mucosal tissues: implications for prevention of HIV-1 transmission. Sci Transl Med 2011;3(112):112re4.

21. Cottrell ML, Garrett KL, Prince HMA, et al. Single-dose pharmacokinetics of tenofovir alafenamide and its active metabolite in the mucosal tissues. J Antimicrob Chemother 2017;72(6):1731-40.

22. Di Mascio M, Srinivasula S, Bhattacharjee A, et al. Antiretroviral tissue kinetics: in vivo imaging using positron emission tomography. Antimicrob Agents Chemother 2009;53(10):4086-95.

23. Twigg $\mathrm{HL}$, Schnizlein-Bick $\mathrm{CT}$, Weiden $\mathrm{M}$, et al. Measurement of antiretroviral drugs in the lungs of HIV-infected patients. HIV Ther 2010;4(2):247-51.

24. Melchjorsen J, Ris $\varnothing r$ MW, Søgaard OS, et al. Tenofovir selectively regulates production of inflammatory cytokines and shifts the IL-12/IL-10 balance in human primary cells. J Acquir Immune Defic Syndr 1999 2011;57(4):265-75.

25. Zídek Z, Franková D, Holý A. Activation by 9-(R)-[2-

(phosphonomethoxy)propyl]adenine of chemokine (RANTES, macrophage inflammatory protein 1alpha) and cytokine (tumor necrosis factor alpha, interleukin-10 [IL-10], IL-1beta) production. Antimicrob Agents Chemother 2001;45(12):3381-6.

26. Zídek Z, Potmesil P, Kmoníèková E, Holý A. Immunobiological activity of N-[2(phosphonomethoxy)alkyl] derivatives of N6-substituted adenines, and 2,6-diaminopurines. Eur J Pharmacol 2003;475(1-3):149-59. 
medRxiv preprint doi: https://doi.org/10.1101/2021.11.11.21266189; this version posted November 11,2021 . The copyright holder for this preprint (which was not certified by peer review) is the author/funder, who has granted medRxiv a license to display the preprint in

All rights reserved. No reuse allowed without permission.

27. Kostecká P, Holý A, Farghali H, Zídek Z, Kmoníčková E. Differential effects of acyclic nucleoside phosphonates on nitric oxide and cytokines in rat hepatocytes and macrophages. Int Immunopharmacol 2012;12(2):342-9.

28. Park S-J, Yu K-M, Kim Y-I, et al. Antiviral Efficacies of FDA-Approved Drugs against SARS-CoV-2 Infection in Ferrets. mBio 2020;11(3).

29. Parienti J-J, Prazuck T, Peyro-Saint-Paul L, et al. Effect of Tenofovir Disoproxil Fumarate and Emtricitabine on nasopharyngeal SARS-CoV-2 viral load burden amongst outpatients with COVID-19: A pilot, randomized, open-label phase 2 trial. EClinicalMedicine 2021;38:100993.

30. Gaitán-Duarte HG, Álvarez-Moreno C, Rincón-Rodríguez CJ, et al. Effectiveness of Rosuvastatin plus Colchicine, Emtricitabine/Tenofovir and a combination of them in Hospitalized Patients with SARS Covid-19 [Internet]. 2021 [cited 2021 Oct 5]. Available from: https://www.medrxiv.org/content/10.1101/2021.07.06.21260085v1

31. Plan Nacional sobre el Sida (PNS). Prevention of SARS-CoV-2 (COVID-19) Through PreExposure Prophylaxis With Tenofovir Disoproxil Fumarate/Emtricitabine and Hydroxychloroquine in Healthcare Personnel: Randomized Clinical Trial Controlled With Placebo [Internet]. clinicaltrials.gov; 2021 [cited 2021 Oct 4]. Available from: https://clinicaltrials.gov/ct2/show/NCT04334928

32. Instituto de Investigación Hospital Universitario La Paz. Randomized Clinical Trial to Evaluate the Efficacy of Different Treatments in Patients With COVID-19 [Internet]. clinicaltrials.gov; 2021 [cited $2021 \mathrm{Jul} 6$ ]. Available from: https://clinicaltrials.gov/ct2/show/NCT04890626

33. Lima AÂM. Clinical, Control, Double-blind, Randomized Experimentation With Tenofovir Disoproxyl Fumarate and Emtricitabine for COVID-19 [Internet]. clinicaltrials.gov; 2021 [cited 2021 Oct 4]. Available from: https://clinicaltrials.gov/ct2/show/NCT04712357

34. Pilkington V, Hill A, Hughes S, Nwokolo N, Pozniak A. How safe is TDF/FTC as PrEP? A systematic review and meta-analysis of the risk of adverse events in 13 randomised trials of PrEP. J Virus Erad 2018;4(4):215-24.

35. Palacios R, Hidalgo C, Ríos MJ, et al. Effectiveness and safety of simplification from tenofovir-lamivudine (TDF-3TC) to tenofovir-emtricitabine (TDF-FTC) co-formulation (Truvada) in virologically suppressed HIV-infected patients on HAART. Eur J Clin Microbiol Infect Dis Off Publ Eur Soc Clin Microbiol 2009;28(4):399-402.

36. Hernandez-Diaz S, Bateman BT, Straub L, et al. Safety of Tenofovir Disoproxil Fumarate (TDF) for Pregnant Women facing the COVID-19 Pandemic. Am J Epidemiol 2021;kwab109. 
medRxiv preprint doi: https://doi.org/10.1101/2021.11.11.21266189; this version posted November 11,2021 . The copyright holder for this preprint (which was not certified by peer review) is the author/funder, who has granted medRxiv a license to display the preprint in perpetuity.

All rights reserved. No reuse allowed without permission.

Table 1. Baseline characteristics of 51,558 eligible individuals by NRTI combination in HIV-positive individuals, CoVIHd Collaboration, Spain, February-December 2020

\begin{tabular}{|c|c|c|c|c|}
\hline & $\begin{array}{c}\text { TAF/FTC } \\
\mathbf{N}=\mathbf{2 0 , 4 3 2} \\
(\mathbf{3 9 . 6 \% )}\end{array}$ & $\begin{array}{c}\text { TDF/FTC } \\
\mathbf{N}=\mathbf{6 , 1 6 0} \\
(\mathbf{1 1 . 9 \% )}\end{array}$ & $\begin{array}{c}\text { ABC/3TC } \\
\mathbf{N}=\mathbf{1 3 , 7 1 5} \\
(\mathbf{2 6 . 6 \% )}\end{array}$ & $\begin{array}{c}\text { Other regimes } \\
\mathbf{N}=\mathbf{1 1 , 2 5 1} \\
(\mathbf{2 1 . 8 \% )}\end{array}$ \\
\hline \multicolumn{5}{|l|}{$\operatorname{Sex}[N(\%)]$} \\
\hline Men & $16,527(80.9)$ & $4,856(78.8)$ & $10,797(78.7)$ & $8,623(76.6)$ \\
\hline Women & 3,905 (19.1) & $1,304(21.2)$ & $2,918(21.3)$ & $2,628(23.4)$ \\
\hline \multicolumn{5}{|l|}{ Age, years } \\
\hline [Median (IQR)] & $49(39-56)$ & $48(39-55)$ & $51(41-57)$ & $53(45-58)$ \\
\hline \multicolumn{5}{|c|}{ Transmission category [N (\%)] } \\
\hline Heterosexual contact & $4,652(22.8)$ & $1,463(23.7)$ & $3,218(23.5)$ & $2,726(24.2)$ \\
\hline Homo/bisexual contact & 8,939 (43.7) & $2,221(36.1)$ & $4,859(35.4)$ & $3,741(33.2)$ \\
\hline Injecting drug use & $3,501(17.1)$ & $1,242(20.2)$ & $2,665(19.4)$ & $2,847(25.3)$ \\
\hline Other & $503(2.5)$ & $147(2.4)$ & $300(2.2)$ & $328(2.9)$ \\
\hline Unknown & 2,837 (13.9) & $1,087(17.6)$ & $2,673(19.5)$ & $1,609(14.3)$ \\
\hline \multicolumn{5}{|l|}{ Country of origin [N (\%)] } \\
\hline Spain & $12,632(61.8)$ & $3,836(62.3)$ & $8,553(62.4)$ & $8,077(71.8)$ \\
\hline Other & $4,689(22.9)$ & $1,367(22.2)$ & 2,325 (16.9) & $1,568(13.9)$ \\
\hline Unknown & $3,111(15.2)$ & $957(15.5)$ & $2,837(20.7)$ & $1,606(14.3)$ \\
\hline \multicolumn{5}{|l|}{ CD4 cell count, cells $/ \mathrm{mm}^{3}$} \\
\hline Median (IQR) & 704 (509-933) & 700 (511-929) & 746 (536-994) & $718(520-948)$ \\
\hline$<350$ & $2,059(10.1)$ & $619(10.0)$ & $1,179(8.6)$ & $1,014(9.0)$ \\
\hline $350-500$ & $2,775(13.6)$ & $834(13.5)$ & $1,735(12.6)$ & $1,504(13.4)$ \\
\hline$>500$ & $15,414(75.4)$ & $4,671(75.8)$ & $10,718(78.1)$ & $8,620(76.6)$ \\
\hline Unknown & $184(0.9)$ & $36(0.6)$ & $83(0.6)$ & $113(1.0)$ \\
\hline \multicolumn{5}{|l|}{ Hypertension [N (\%)] } \\
\hline No & $16,804(82.2)$ & $5,388(87.5)$ & $10,897(79.4)$ & $8,469(75.3)$ \\
\hline Yes & $3,091(15.1)$ & $695(11.3)$ & $2,589(18.9)$ & $2,564(22.8)$ \\
\hline Unknown & $537(2.6)$ & $77(1.2)$ & $229(1.7)$ & $218(1.9)$ \\
\hline \multicolumn{5}{|l|}{ Diabetes [N (\%)] } \\
\hline No & $18,490(90.5)$ & 5,707 (92.6) & $12,217(89.1)$ & $9,736(86.5)$ \\
\hline Yes & $1,486(7.3)$ & $380(6.2)$ & $1,302(9.5)$ & $1,305(11.6)$ \\
\hline Unknown & $456(2.2)$ & $73(1.2)$ & $196(1.4)$ & 210 (1.9) \\
\hline \multicolumn{5}{|c|}{ Chronic renal disease [N (\%)] } \\
\hline No & $19,375(94.8)$ & $5,952(96.6)$ & $12,570(91.6)$ & $10,028(89.1)$ \\
\hline Yes & $1,057(5.2)$ & $208(3.4)$ & $1,145(8.3)$ & $1,223(10.9)$ \\
\hline \multicolumn{5}{|c|}{ Cardiovascular disease [N (\%)] } \\
\hline No & $16,628(81.4)$ & $5,511(89.5)$ & $11,759(85.7)$ & $9,568(85.0)$ \\
\hline Yes & $1,051(5.1)$ & $302(4.9)$ & $773(5.6)$ & $887(7.9)$ \\
\hline Unknown & $2,753(13.5)$ & $347(5.6)$ & $1,183(8.6)$ & $796(7.1)$ \\
\hline \multicolumn{5}{|l|}{$\begin{array}{l}\text { Treatment with } \\
\text { immunosuppressants or } \\
\text { corticosteroids [N (\%) }\end{array}$} \\
\hline No & $13,631(66.7)$ & 4,313 (70.0) & 8,768 (63.9) & $7,805(69.4)$ \\
\hline Yes & $174(0.8)$ & $78(1.3)$ & $163(1.2)$ & $142(1.3)$ \\
\hline Unknown & $6,627(32.4)$ & $1,769(28.7)$ & $4,784(34.9)$ & $3,304(29.4)$ \\
\hline
\end{tabular}




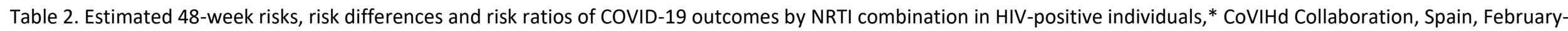
December 2020

Documented SARS-CoV-2 infection

$\begin{array}{lcccc} & \begin{array}{c}\text { No. } \\ \text { events }\end{array} & \begin{array}{c}\text { Risks } \\ (95 \% \mathrm{Cl}), \\ \%\end{array} & \begin{array}{c}\text { Risk } \\ \text { Differences } \\ (95 \% \mathrm{Cl}), \%\end{array} & \begin{array}{c}\text { Risk Ratios } \\ (95 \% \mathrm{Cl})\end{array} \\ \text { TAF/FTC } & 923 & \begin{array}{c}4.3 \\ (4.1,4.6)\end{array} & 0 & 1.00 \\ & & & \\ \text { TDF/FTC } & 300 & 4.5 & 0.16 & 1.04 \\ & & (3.9,5.0) & (-0.48,0.69) & (0.89,1.17) \\ \text { ABC/3TC } & 687 & 5.2 & 0.89 & 1.21 \\ & & (4.8,5.6) & (0.40,1.34) & (1.09,1.33) \\ \begin{array}{l}\text { Other } \\ \text { regimes }\end{array} & 492 & 4.6 & 0.24 & 1.06 \\ & & (4.1,5.0) & (-0.27,0.77) & (0.94,1.18)\end{array}$

Hospitalization due to COVID-19

\begin{tabular}{|c|c|c|}
\hline $\begin{array}{c}\text { Risks } \\
(95 \% \mathrm{Cl}), \\
\%\end{array}$ & $\begin{array}{c}\text { Risk } \\
\text { Differences } \\
(95 \% \mathrm{Cl}), \%\end{array}$ & $\begin{array}{c}\text { Risk Ratios } \\
(95 \% \mathrm{Cl})\end{array}$ \\
\hline $\begin{array}{c}0.8 \\
(0.7,1.0)\end{array}$ & 0 & 1.00 \\
\hline $\begin{array}{c}0.5 \\
(0.4,0.7)\end{array}$ & $\begin{array}{c}-0.28 \\
(-0.52,-0.08)\end{array}$ & $\begin{array}{c}0.66 \\
(0.43,0.91)\end{array}$ \\
\hline $\begin{array}{c}1.1 \\
(0.9,1.2)\end{array}$ & $\begin{array}{c}0.24 \\
(0.02,0.45)\end{array}$ & $\begin{array}{c}1.29 \\
(1.02,1.58)\end{array}$ \\
\hline $\begin{array}{c}0.7 \\
(0.5 .8)\end{array}$ & $\begin{array}{c}-0.16 \\
(-0.34 .04)\end{array}$ & $\begin{array}{c}0.81 \\
(0.62105)\end{array}$ \\
\hline
\end{tabular}

ICU admission due to COVID-19

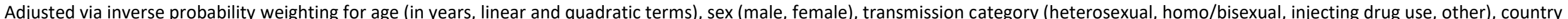

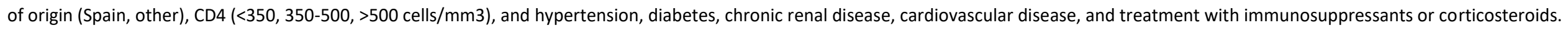


Table 3. Estimated 48-week risk, risk differences and risk ratios of COVID-19 outcomes by NRTI combination in HIV-positive individuals, stratified by age group, ${ }^{*}$ CoVIHd Collaboration, Spain, February-December 2020

\begin{tabular}{|c|c|c|c|c|c|c|c|c|}
\hline & \multicolumn{4}{|c|}{ Documented SARS-CoV-2 infection } & \multicolumn{4}{|c|}{ Hospitalization due to COVID-19 } \\
\hline & $\begin{array}{c}\text { No. } \\
\text { events }\end{array}$ & $\begin{array}{c}\text { Risks } \\
(95 \% \mathrm{Cl}), \%\end{array}$ & $\begin{array}{c}\text { Risk Differences } \\
(95 \% \mathrm{Cl}), \%\end{array}$ & $\begin{array}{l}\text { Risk Ratios } \\
(95 \% \mathrm{Cl})\end{array}$ & $\begin{array}{c}\text { No. } \\
\text { events }\end{array}$ & $\begin{array}{c}\text { Risks } \\
(95 \% \mathrm{Cl}), \%\end{array}$ & $\begin{array}{c}\text { Risk Differences } \\
(95 \% \mathrm{Cl}), \%\end{array}$ & Risk Ratios $(95 \% \mathrm{Cl})$ \\
\hline \multicolumn{9}{|l|}{$<50$ years } \\
\hline TAF/FTC & 561 & $4.9(4.5,5.3)$ & 0 & 1.00 & 48 & $0.4(0.3,0.6)$ & 0 & 1.00 \\
\hline TDF/FTC & 198 & $5.3(4.6,6.0)$ & $0.45(-0.43,1.25)$ & $1.09(0.91,1.27)$ & 18 & $0.5(0.3,0.8)$ & $0.06(-0.21,0.34)$ & $1.15(0.59,1.93)$ \\
\hline $\mathrm{ABC} / 3 \mathrm{TC}$ & 336 & $5.4(4.8,6.0)$ & $0.50(-0.27,1.21)$ & $1.10(0.95,1.26)$ & 29 & $0.5(0.3,0.6)$ & $0.02(-0.22,0.22)$ & $1.03(0.59,1.62)$ \\
\hline $\begin{array}{l}\text { Other } \\
\text { regimes }\end{array}$ & 220 & $5.4(4.7,6.0)$ & $0.47(-0.35,1.23)$ & $1.10(0.93,1.26)$ & 17 & $0.4(0.2,0.6)$ & $-0.04(-0.26,0.17)$ & $0.91(0.49,1.47)$ \\
\hline \multicolumn{9}{|l|}{$\geq 50$ years } \\
\hline TAF/FTC & 362 & $3.8(3.4,4.2)$ & 0 & 1.00 & 109 & $1.2(1.0,1.4)$ & 0 & 1.00 \\
\hline TDF/FTC & 102 & $3.6(2.9,4.3)$ & $-0.17(-0.94,0.64)$ & $0.96(0.77,1.18)$ & 17 & $0.6(0.3,0.9)$ & $-0.61(-1.03,-0.22)$ & $0.49(0.24,0.81)$ \\
\hline $\mathrm{ABC} / 3 \mathrm{TC}$ & 351 & $5.0(4.6,5.6)$ & $1.26(0.62,1.89)$ & $1.33(1.15,1.55)$ & 118 & $1.7(1.4,2.0)$ & $0.47(0.11,0.83)$ & $1.40(1.08,1.79)$ \\
\hline $\begin{array}{l}\text { Other } \\
\text { regimes }\end{array}$ & 272 & $3.9(3.4,4.3)$ & $0.07(-0.51,0.64)$ & $1.02(0.87,1.18)$ & 69 & $0.9(0.7,1.1)$ & $-0.29(-0.62,0.03)$ & $0.76(0.54,1.03)$ \\
\hline
\end{tabular}

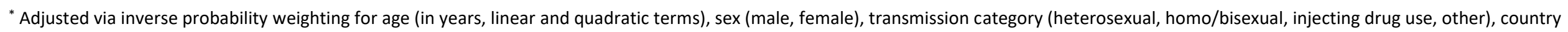

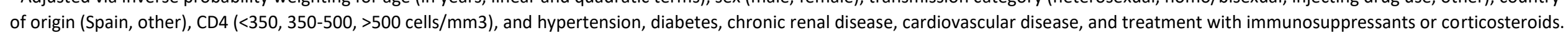


Figure 1. Flowchart of study population among HIV-positive individuals, CoVIHd Collaboration, Spain, February-December 2020

65,569 HIV-positive individuals receiving antiretroviral therapy during 2020

14,011 excluded from analysis

718 with no data on sex

91 with no data on date of birth

$16<18$ years

1,703 with no data on HIV RNA

4,729 with HIV RNA > 50 copies/ml

2 diagnosed with SARS-CoV-2 infection in January 2020

1,687 not on ART on February 1, 2020

187 with no data on type of ART regimen

1 with date of COVID-19 hospitalization before diagnosis of SARS-CoV-2 infection

4,877 with no data on presence of chronic renal disease

$\mathbf{5 1 , 5 5 8}$ HIV-positive individuals on antiretroviral therapy on February 1, 2020

20,432 TAF/FTC

6,160 TDF/FTC

$13,715 \mathrm{ABC} / 3 \mathrm{TC}$

11,251 Other regimes 
Figure 2. Estimated risks of COVID-19 outcomes by NRTI combination in HIV-positive individuals, *CoVIHd Collaboration, Spain, February-December 2020

\section{A. Documented SARS-CoV-2 infection}

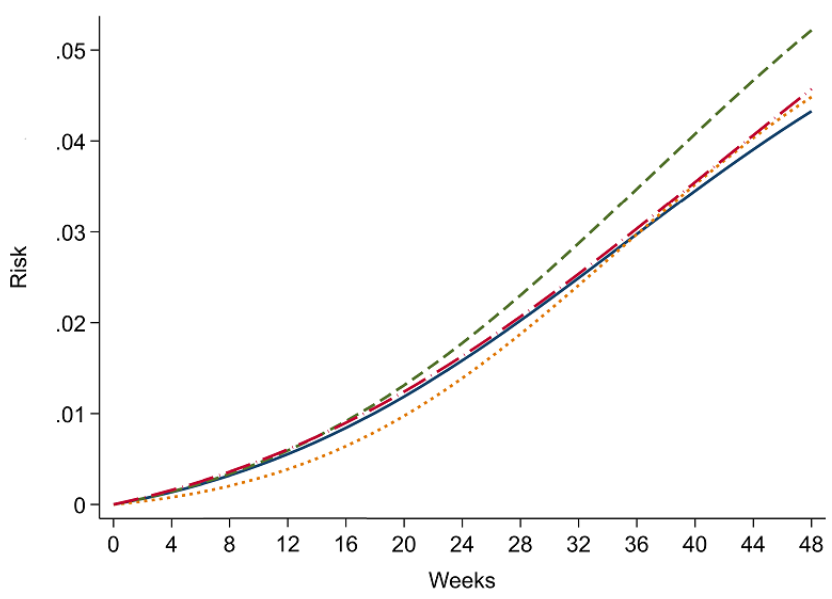

C. Intensive care unit admission due to COVID-19

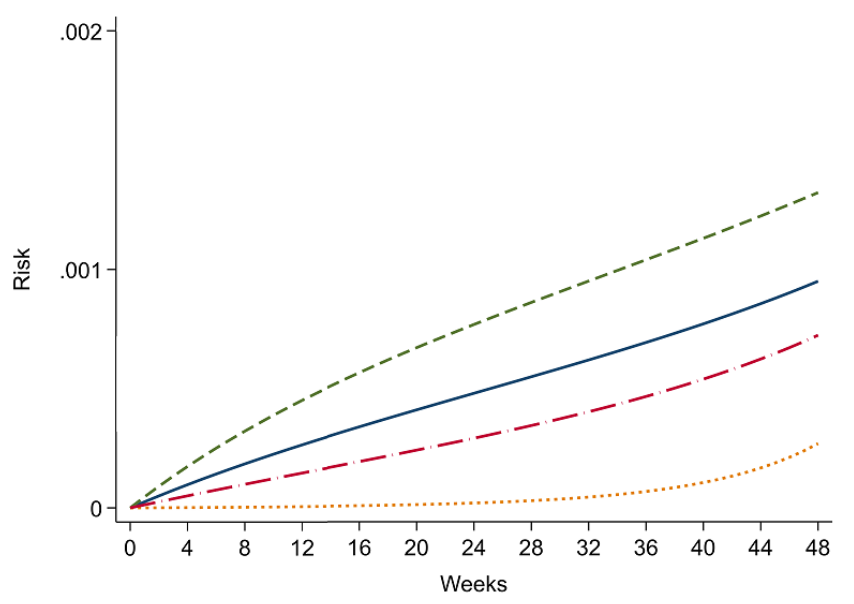

B. Hospitalization due to COVID-19

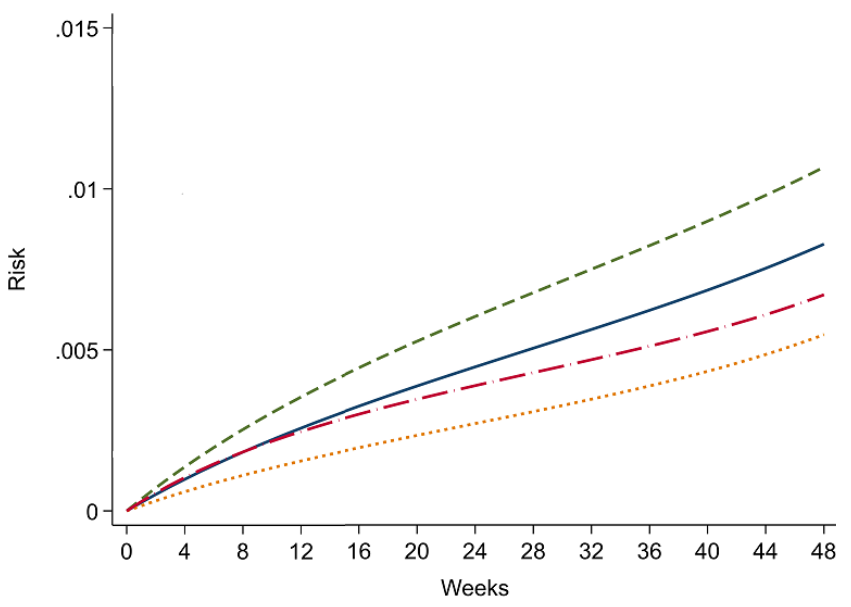

D. COVID-19 death

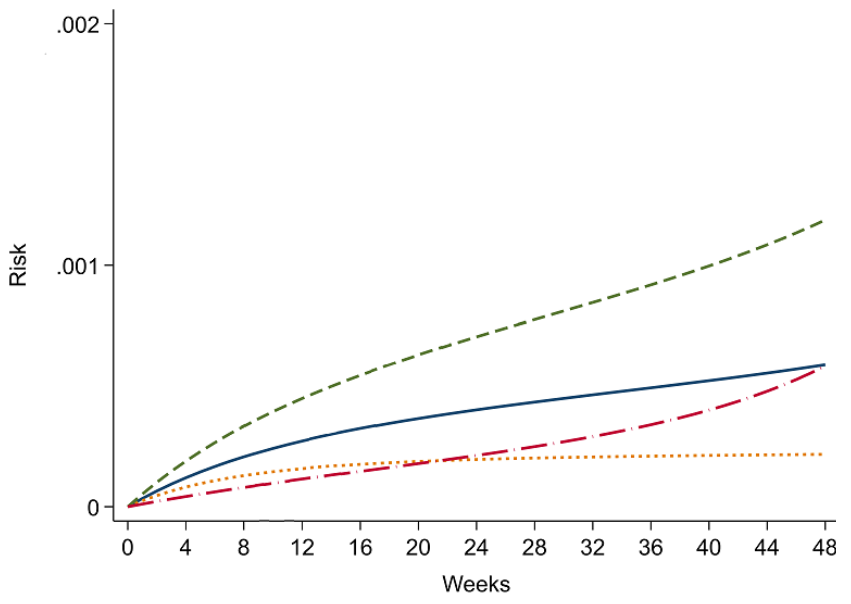

$$
\text { TAF/FTC } \cdots \ldots \ldots \text { TDF/FTC }----A B C / 3 T C-\cdot-\text { Other }
$$

${ }^{*}$ Adjusted via inverse probability weighting for age (in years, linear and quadratic terms), sex (male, female), transmission category (heterosexual, homo/bisexual, injecting drug use, other), country of origin (Spain, other), CD4 (<350, 350-500, >500 cells/mm3), and hypertension, diabetes, chronic renal disease, cardiovascular disease, and treatment with immunosuppressants or corticosteroids. 